\section{Acanthomatous Ameloblastoma}

Leila Salera $^{1}$ and Jay Hansel Tabije ${ }^{2}$

${ }^{1}$ Global Medical Center of Laguna, Cabuyao City, Laguna, Philippines

${ }^{2}$ Saint Jude Hospital and Medical Center, Sampaloc, Manila, Philippines

\section{Key words: ameloblastoma, acanthomatous,} odontogenic
A 22-year-old female noticed a $1.0 \times 1.0 \mathrm{~cm}$ gingival mass of one-year duration. Two months prior to consult, a panoramic radiograph was performed, revealing a defined unicystic, mixed radiopaque and radiolucent lesion between the premolars on the right hemi-mandible, causing displacement on the roots of the premolar without signs of resorption and not associated with any unerupted tooth (Figure 1). Physical examination revealed a swelling at the right mandibular premolar area (Figure 2). Enucleation with peripheral ostectomy was performed and the mass was submitted for histopathologic examination. The patient was advised follow-up.

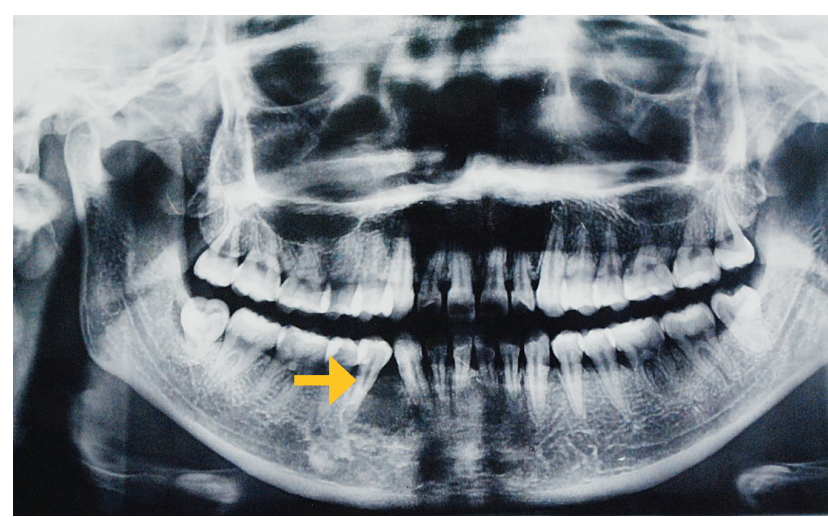

Figure 1. Radiographic appearance of the lesion.

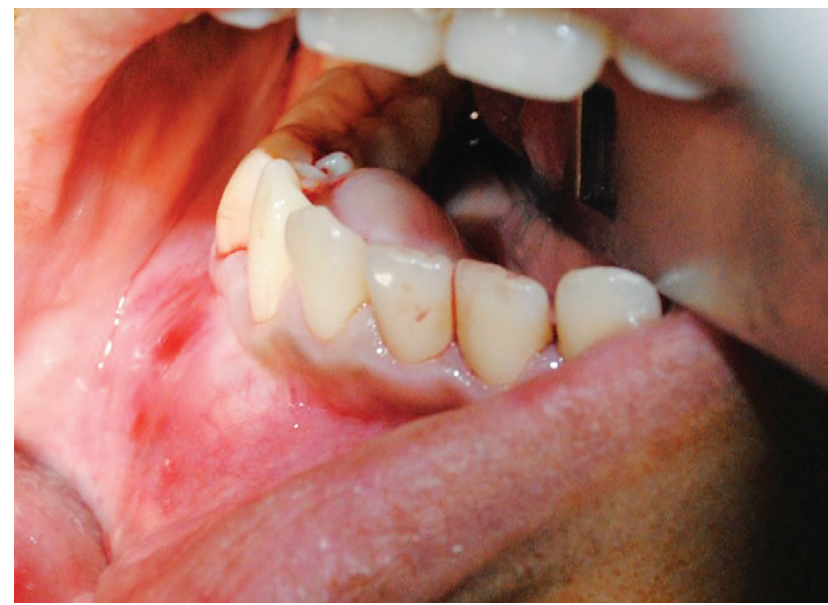

Figure 2. Clinical appearance of the lesion.

Histopathologic examination revealed a lesion composed of odontogenic epithelial islands with peripheral palisading columnar basal cells and central stellate reticulum. The basal cells have vacuolated cytoplasm with nuclei exhibiting reverse polarity (Figure 3). Microcysts and squamous differentiation were seen. (Figure 4). The morphologic features were consistent with an acanthomatous ameloblastoma. 


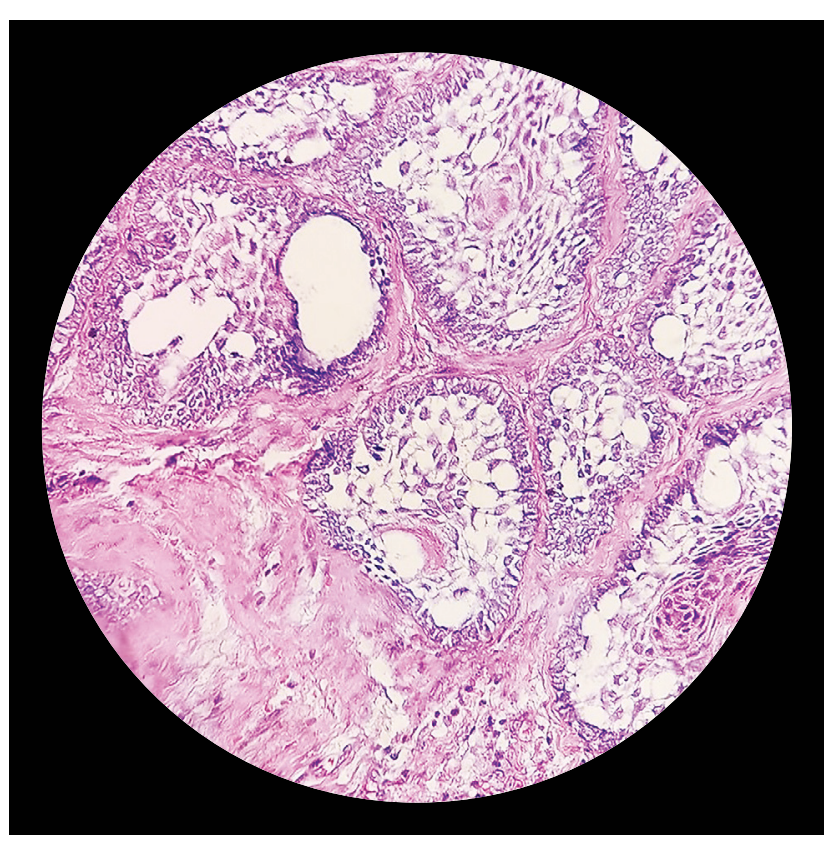

Figure 3. Odontogenic islands, central stellate reticulum palisading basal cells, and reverse polarity of the nuclei ( $H \& E, 40 x)$.

Ameloblastoma is a benign odontogenic tumor that comprises about $1 \%$ of all oral tumors and $9-11 \%$ of odontogenic tumors. ${ }^{1-4}$ Over $80 \%$ occur in the mandible and $20 \%$ in the maxilla. ${ }^{3,5,6}$ It has no sex predilection, has a wide age range, and appears as a lytic expansile lesion radiographically. ${ }^{2,5,7}$ Depending on the appearance of the central reticulum, the terms spindle cell, granular, basal cell and acanthomatous are used. The term acanthomatous ameloblastoma is used when the central stellate reticulum displays squamous differentiation. ${ }^{8}$

Ameloblastoma is placed under borderline (low-grade malignant) category, rather than benign, due to its aggressive properties and tendency to recur. Although rare, metastases have been documented. ${ }^{5}$

\section{REFERENCES}

1. Masthan KMK, Anitha N, Krupaa N, Manikkam S. Ameloblastoma.J Pharm BioAllied Sci. 2015;7(Suppl 1):S16770. PMCID: PMC4439660. https://doi.org/10.4103/09757406.155891

2. Chukwuneke FN, Anyanechi CE, Akpeh JO, Chukwuka A, Ekwueme OC. Clinical characteristic and presentation of ameloblastoma: an 8-year retrospective study of 240 cases in Eastern Nigeria. Br J Oral Maxillofac Surg. 2016;54(4):384-7. PMID: 26387072. https://doi.org/10.1016/j. bjoms.2015.08.264.

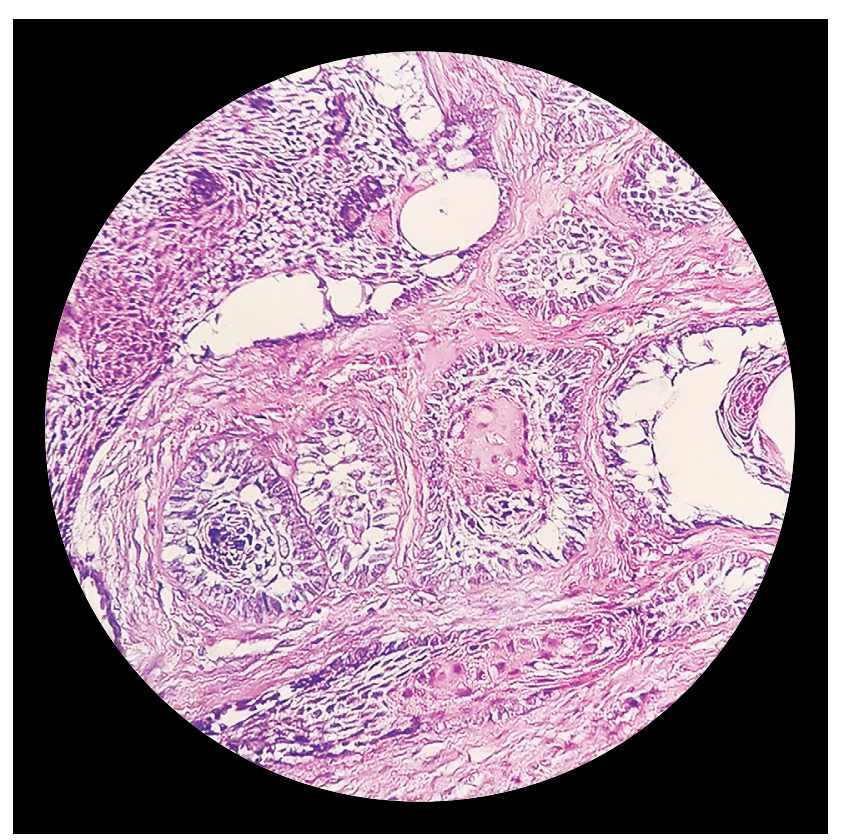

Figure 4. Microcyts and squamous differentiation (H \& E, 40x).

3. Neville WB, Damm DD, Allen CM, Bouquot JE. Oral and Maxillofacial Pathology, 2nd ed. WB Saunders Company; 2002, pp. 611-20.

4. Fulco GM, Nonaka CF, Souza LB, Miguel MC, Pinto LP. Solid ameloblastomas - Retrospective clinical and histopathologic study of 54 cases. Braz J Otorhinolaryngol. 2010;76(2):172-7. PMID: 20549076.

5. Barnes L, Eveson JW, Reichart P, Sidransky D. World Health Organization classification of tumors. Pathology and genetics. Head and neck tumors. Lyon France: IARC Press; 2005, pp. 1-430. Available from: https://www.iarc.fr/en/publications/ pdfs-online/pat-gen/bb9/BB9.pdf.

6. Rosai and Ackerman's Surgical Pathology,10th ed.; 2011.

7. Magliocca K, Martinez A. Mandible-maxilla benign tumors ameloblastoma. Retrievedfromhttp://www.pathologyoutlines. com/topic/mandiblemaxillaameloblastoma.html. Accessed March 2017.

8. Saghravanian N, Salehinejad, Ghazi N, Shirdel M, Razi M. A 40-year retrospective clinicopathological study of ameloblastoma in Iran. Asian Pac J Cancer Prev. 2016;17(2), 619-23. PMID: 26925653.

Disclaimer: This journal is OPEN ACCESS, providing immediate access to its content on the principle that making research freely available to the public supports a greater global exchange of knowledge. As a requirement for submission to the PJP, all authors have accomplished an AUTHOR FORM, which declares that the ICMJE criteria for authorship have been met by each author listed, that the article represents original material, has not been published, accepted for publication in other journals, or concurrently submitted to other journals, and that all funding and conflicts of interest have been declared. Consent forms have been secured for the publication of information about patients or cases; otherwise, authors have declared that all means have been exhausted for securing consent. 